Nowoczesne Systemy Zarządzania

Zeszyt 12 (2017), nr 2 (kwiecień-czerwiec)

ISSN 1896-9380, s. 251-262

Modern Management Systems

Volume 12 (2017), No. 2 (April-June)

ISSN 1896-9380, pp. 251-262

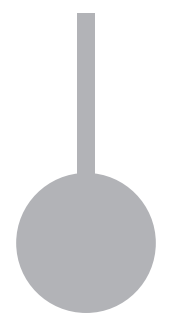

Instytut Organizacji i Zarządzania

Wydział Cybernetyki

Wojskowa Akademia Techniczna

w Warszawie

Institute of Organization and Management

Faculty of Cybernetics

Military University of Technology

\title{
Analiza możliwości wdrożenia zasad zrównoważonych zamówień publicznych w Polsce
}

\section{Analysis of the possibility of applying the principles of the sustainable public procurement in Poland}

\author{
Agnieszka Ścisło \\ Wojskowa Akademia Techniczna, Wydział Cybernetyki \\ agnieszka@scislo.pl
}

\begin{abstract}
Abstrakt: Idea zrównoważonych zamówień publicznych (ZZP) zakłada, że instytucje zamawiające powinny uwzględniać w procesie zakupowym kwestie wpływu zamówień na środowisko, gospodarkę lokalną i sferę socjalną. Jednak zamawiający niechętnie korzystają z możliwości wdrożenia zasad ZZP w praktyce. Celem pracy jest przedstawienie idei zrównoważonych zamówień publicznych, identyfikacja barier w jej stosowaniu obecnie w Polsce oraz sformułowanie propozycji działań zmierzających do upowszechnienia realizacji zasad ZZP. Można wyróżnić trzy główne rodzaje barier w stosowaniu tej idei w praktyce: bariery związane z wiedzą i umiejętnościami osób przygotowujących zamówienia oraz osób sprawujących funkcje kontrolne, bariery psychologiczne (obawy i postawy) osób zamawiających oraz bariera finansowa (wyższe koszty zamówień uwzględniających zasady ZZP w porównaniu do pozostałych zamówień). Upowszechnienie stosowania zasad ZZP wymaga realizacji przez Urząd Zamówień Publicznych oraz inne instytucje państwowe intensywnych działań edukacyjnych i promocyjnych.
\end{abstract}

Słowa kluczowe: zamówienia publiczne, handel internetowy, platformy zakupowe, zaopatrzenie.

Abstract: Public procurement has a great impact on the economy of the whole country, as well as on the development of the local market, labor market and natural environment. The idea of sustainable procurement implies that public organizations should take those issues into account in their procurement process. However, the contracting authorities are reluctant to implement the rules of SP. We can point three barriers to applying this idea in practice: barriers: barriers related to the knowledge and skills of order preparers and control persons, psychological barriers (fears and attitudes) of order preparers and the financial barrier (higher costs of sustainable public procurement compared to other orders). Dissemination of the application o sustainable procurement requires educational and promotional activities of the Public Procurement Office and other state institutions.

Keywords: public procurement, e-commerce, e-commerce platforms, procurement. 


\section{Wstęp}

Zakupy ze środków publicznych mają znaczący wpływ na gospodarkę w skali makro, ale również na rozwój rynku lokalnego, rynek pracy oraz środowisko naturalne. Idea zrównoważonych zamówień publicznych (ZZP) zakłada, że instytucje zamawiające będą uwzględniały te kwestie w procesie zakupowym. Jednak zamawiający niechętnie korzystają z możliwości wdrożenia zasad ZZP.

Celem pracy jest przedstawienie idei zrównoważonych zamówień publicznych, identyfikacja barier w jej stosowaniu obecnie w Polsce oraz sformułowanie propozycji działań zmierzających do upowszechnienia realizacji zasad ZZP.

Metody badawcze wykorzystane w pracy to analiza literatury, indukcja i synteza.

\section{Rynek zamówień publicznych w Polsce}

Zamówienia publiczne mają znaczący wpływ na gospodarkę każdego kraju. Ogółem wartość rynku zamówień publicznych w Polsce w ostatnich latach oscyluje wokół 7\% produktu krajowego brutto. W 2015 roku całkowita wartość zamówień wyniosła 116,3 mld zł, co stanowiło 6,5\% PKB (UZP, 2016a, s. 27).

Największą grupę zamawiających w 2015 r. stanowiła administracja samorządowa $(71,77 \%)$. Inne grupy podmiotów zamawiających to: administracja rządowa terenowa, samodzielne publiczne zakłady opieki zdrowotnej, państwowe jednostki organizacyjne nieposiadające osobowości prawnej, zamawiający udzielający zamówień sektorowych, administracja rządowa centralna, uczelnie publiczne, instytucje ubezpieczenia społecznego i zdrowotnego i in. (UZP, 2016a, s. 28). W tym czasie $35 \%$ zamówień publicznych stanowiły zamówienia na dostawy, 33\% - na roboty budowlane i $32 \%$ na usługi.

Procedury związane z przeprowadzeniem zamówienia publicznego określone są w Ustawie o zamówieniach publicznych. Najczęściej stosowane formy postępowań to przetarg nieograniczony (83,39\% ogólnej liczby zamówień w 2015 r.) i zamówienie „Z wolnej ręki” (11,75\%) (UZP, 2016a, s. 31).

Przetarg nieograniczony to taki tryb udzielania zamówienia, w którym „w odpowiedzi na publiczne ogłoszenie o zamówieniu, oferty mogą składać wszyscy zainteresowani wykonawcy" (Prawo zamówień publicznych, 2004, art. 39). W przypadku zamówienia „Z wolnej ręki” zamawiający prowadzi negocjacje tylko z jednym wykonawcą.

Do pozostałych trybów zamówień, możliwych do zastosowania w określonych warunkach, należą:

- negocjacje z ogłoszeniem - zamawiający publikuje ogłoszenie o zamówieniu, a następnie zaprasza podmioty dopuszczone do udziału w postępowaniu 
do składania ofert wstępnych, niezawierających ceny; następnie prowadzi z nimi negocjacje, po których składane są oferty;

- negocjacje bez ogłoszenia - zamawiający negocjuje warunki umowy $\mathrm{z}$ wybranymi przez siebie wykonawcami, a następnie zaprasza ich do złożenia ofert;

- dialog konkurencyjny - po opublikowaniu ogłoszenia zamawiający prowadzi $\mathrm{z}$ wybranymi wykonawcami dialog, a następnie zaprasza ich do składania ofert;

- zapytanie o cenę - zamawiający kieruje pytanie o cenę do wybranych przez siebie wykonawców i zaprasza ich do składania ofert;

- licytacja elektroniczna - do przeprowadzenia licytacji elektronicznej konieczne jest udostępnienie wykonawcom zamówienia formularza internetowego, za pomocą którego mogą składać kolejne (coraz korzystniejsze dla zamawiającego) oferty, podlegające automatycznej klasyfikacji (Prawo zamówień publicznych, 2004, art. 47-81).

W nowelizacji ustawy Prawo zamówień publicznych obowiązującej od 28 lipca 2016 roku pojawił się nowy tryb zamówień: partnerstwo innowacyjne. Jest to „tryb udzielenia zamówienia, w którym w odpowiedzi na publiczne ogłoszenie o zamówieniu, zamawiający zaprasza wykonawców dopuszczonych do udziału w postępowaniu do składania ofert wstępnych, prowadzi z nimi negocjacje, a następnie zaprasza do składania ofert na opracowanie innowacyjnego produktu, usług lub robót budowlanych niedostępnych na rynku oraz sprzedaż tych produktów, usług lub robót budowlanych" (Prawo zamówień publicznych, 2004, art. 73a).

Jednym z głównych problemów rynku zamówień publicznych w Polsce jest tzw. „dyktat najniższej ceny”. Zgodnie z ustawą Prawo zamówień publicznych z 2004 roku, możliwe było ustalanie pozacenowych kryteriów oceny ofert. Jednak $\mathrm{w}$ praktyce zamawiający bardzo często stosowali wyłącznie kryterium ceny (w roku 2014 - w 75\%; w 2013 - w 85\%, a w 2012 - w 76\% postępowań (UZP, 2016a, s. 35)). Powodów takiego stanu rzeczy można upatrywać w obawie zamawiających przed zarzutami o niegospodarność lub korupcję oraz w chęci uniknięcia wnoszenia odwołań przez wykonawców. Cena jest parametrem obiektywnym i przejrzystym, co znacznie ułatwiało przeprowadzanie postępowań (KPRM, 23.10.2014).

19 października 2014 roku weszła w życie nowelizacja ustawy Prawo zamówień publicznych, która w założeniu miała ograniczyć zastosowanie kryterium ceny. Wprowadzono zapis mówiący, że „kryterium ceny może być zastosowane jako jedyne kryterium oceny ofert, jeżeli przedmiot zamówienia jest powszechnie dostępny oraz ma ustalone standardy jakościowe" (Prawo zamówień publicznych, 2004, art. 91, ust. 2a).

Wprowadzona nowelizacja nie zmieniła jednak znacząco sytuacji. Wprawdzie spadła liczba postępowań, w których formalnie cena stanowiła jedyne kryterium oceny ofert, ale w praktyce nadal cena miała decydujące znaczenie. Po pierwsze: 
dodatkowe kryteria stanowiły często parametry, co do których oferenci łatwo mogli uzyskać maksymalną liczbę punktów (termin realizacji zamówienia lub okres gwarancji bądź rękojmi) (UZP, 2016a, s. 35). W efekcie oferenci i tak konkurowali ceną. Po drugie: zamawiający często nadawali bardzo wysokie wagi kryterium ceny $(84,07 \%$ zamówień poniżej progów unijnych i 74,16\% powyżej, zawierało wagę parametru „najniższa cena” w przedziale 81-99\% (UZP, 2016a, Załącznik 10)).

28 lipca 2016 roku weszła w życie uchwalona przez Sejm 22 czerwca 2016 r. kolejna nowelizacja ustawy Prawo zamówień publicznych. Zawiera ona zapisy zmierzające do rzeczywistego zmniejszenia roli najniższej ceny, jako głównego kryterium wyboru w zamówieniach publicznych. Zapisy te zostaną omówione w podpunkcie dotyczącym uwarunkowań prawnych wdrażania zasad ZZP.

\section{Główne założenia idei „Zrównoważonych zamówień publicznych"}

Ostatecznym celem każdego zamówienia jest realizacja zadań instytucji sektora publicznego w sposób terminowy i optymalny pod względem nakładów i efektów (Ustawa o finansach publicznych, 2009 art. 44, ust. 3). Jednak należy zauważyć, że decyzje zakupowe instytucji publicznych oddziałują również na środowisko, gospodarkę i społeczeństwo. Analiza tego oddziaływania doprowadziła do powstania idei „Zrównoważonych zamówień publicznych” - ZZP.

Zrównoważone zamówienia publiczne zakładają uwzględnianie przez instytucje publiczne kwestii związanych ze zrównoważonym rozwojem. Zakupy powinny być dobrze przemyślane, niezbędne oraz oddziałujące na środowisko w możliwie najmniejszym stopniu, a także powinny uwzględniać społeczne i ekonomiczne skutki decyzji zakupowych (Sustainable Procurement Platform, 2016).

Zrównoważone zamówienia publiczne zawierają dwa komponenty: społeczny określany jest jako „Społecznie odpowiedzialne zamówienia publiczne” oraz ekologiczny, tzw. „Zielone zamówienia publiczne”.

Społecznie odpowiedzialne zamówienia publiczne to takie zamówienia, które uwzględniają jeden lub kilka następujących aspektów:

- promocja godnej pracy,

- poszanowanie praw człowieka i prawa pracy,

- integracja społeczna (w tym osób niepełnosprawnych),

- promocja równych szans,

- dostępność,

- projektowanie dla wszystkich,

- uwzględnienie kryteriów zrównoważonego rozwoju, w tym kwestii etycznego handlu oraz szerszego dobrowolnego przestrzegania zasad społecznej 
odpowiedzialności biznesu, przy poszanowaniu zasad traktatowych i dyrektyw w sprawie zamówień publicznych (UZP, 2016b).

Zielone zamówienia publiczne (ang. green public procurement - GPP) stanowią proces, w ramach którego instytucje publiczne starają się uzyskać towary, usługi i roboty budowlane, których oddziaływanie na środowisko w trakcie ich cyklu życia jest mniejsze w porównaniu do towarów, usług i robót budowlanych o identycznym przeznaczeniu, jakie zostałyby zamówione w zwykłym trybie (Komisja Wspólnot Europejskich, 2008, s. 6).

Zaleca się, aby proces zakupowy instytucji publicznych był przemyślany i uwzględniał odpowiedzi na następujące pytania:

1. Czy dany produkt jest naprawdę potrzebny? - W ramach odpowiedzi zamawiający powinien zastanowić się nad możliwością ograniczenia zużycia materiałów w instytucji.

2. Czy konieczny jest zakup danego produktu? - Niektóre potrzeby instytucji mogą być zaspokojone przez np. leasing sprzętu lub naprawę bądź modernizację starego.

3. Czy istnieje możliwość zmniejszenia zużycia energii bądź surowców? Rozważyć należy zakup urządzeń i rozwiązań energooszczędnych, w miarę możliwości ograniczających zużycie energii pozyskiwanej z surowców kopalnych.

4. Czy można zmienić specyfikację produktów, tak aby były bardziej przyjazne środowisku i społeczeństwu? - Odpowiadając na to pytanie, zamawiający powinien sprawdzić możliwości zastosowania nowych technologii (Fundacja Centrum CSR.PL, 2014, s. 16).

Zasady ZZP można uwzględnić na różnych etapach postępowania. Przede wszystkim sam przedmiot zamówienia i jego opis mogą być podporządkowane idei ZZP. Zamawiający może również stawiać warunki związane z zasadami ZZP w stosunku do oferentów - zawęzić grono podmiotów uprawnionych do przystąpienia do postępowania. I wreszcie kryteria oceny ofert mogą być określone w sposób zgodny z ZZP.

\section{Ramy prawne stosowania zasad „Zrównoważonych zamówień publicznych" w Polsce}

Plan wdrażania zasad zrównoważonych zamówień publicznych w Unii Europejskiej został ogłoszony w komunikacie Komisji Europejskiej z 2010 r. „Europa 2020, Strategia na rzecz inteligentnego i zrównoważonego rozwoju, sprzyjającego włączeniu społecznemu" (Komisja Europejska, 2010). Obecnie najważniejszym dokumentem określającym stanowisko Unii Europejskiej w tej sprawie jest dyrektywa 2014/24/UE z dnia 26 lutego 2014 r. w sprawie zamówień publicznych. Dyrektywa ta znacznie 
rozszerza możliwości zastosowania już istniejących rozwiązań dotyczących aspektów społecznych oraz wprowadza nowe instrumenty.

Na szczeblu krajowym zasady ZZP znajdujemy w dokumentach strategicznych: "Strategia Bezpieczeństwo Energetyczne i Środowisko - perspektywa do 2020 r.,, „Strategia - Sprawne Państwo 2020 - Dynamiczna Polska” oraz „Strategia Rozwoju Kapitału Społecznego".

W ramach dostosowania do nowej Dyrektywy UE 22 czerwca 2016 roku została znowelizowana obowiązująca w Polsce ustawa Prawo zamówień publicznych. Ustawa ta zawiera wiele zapisów umożliwiających i ułatwiających stosowanie zasad ZZP.

\subsection{Wymagania określone w opisie zamówienia}

W przypadku zamówień dotyczących tworzenia lub nabywania dóbr, z których bezpośrednio korzystają osoby fizyczne, opis przedmiotu zamówienia sporządza się $\mathrm{z}$ uwzględnieniem wymagań w zakresie dostępności dla osób niepełnosprawnych lub projektowania z przeznaczeniem dla wszystkich użytkowników (Prawo zamówień publicznych, 2004, art. 29, pkt. 5).

Istnieje możliwość określenia w opisie przedmiotu zamówienia wymagań związanych ze sposobem realizacji zamówienia. Wymagania te mogą obejmować aspekty gospodarcze, środowiskowe i społeczne. W szczególności mogą one dotyczyć innowacyjności lub zatrudnienia, np. zatrudnienia osób bezrobotnych, młodocianych, niepełnosprawnych, bezdomnych lub nadużywających alkoholu (Prawo zamówień publicznych, 2004, art. 29, pkt. 4).

Kolejny element prospołeczny dotyczy możliwości wymagania wobec wykonawcy lub podwykonawcy zamówienia na usługi lub roboty budowlane, aby osoby wykonujące wskazane przez zamawiającego czynności były zatrudnione na umowę o pracę (Prawo zamówień publicznych, 2004, art. 29, pkt. 3a). Celem takiego działania jest ograniczanie stosowania przez pracodawców tzw. umów śmieciowych.

\subsection{Ograniczenie możliwości składania ofert - zamówienia „zastrzeżone”}

Zamawiający mogą ograniczyć grono potencjalnych oferentów w ramach tzw. zamówienia zastrzeżonego. Artykuł 22 pkt. 2 ustawy mówi, że można skierować zamówienie wyłącznie do zakładów pracy chronionej oraz innych wykonawców, których działalność lub działalność ich wyodrębnionych organizacyjnie jednostek, które będą realizowały zamówienie, obejmuje społeczną i zawodową integrację osób będących członkami grup społecznie marginalizowanych, w szczególności: osób niepełnosprawnych, bezrobotnych, osób pozbawionych wolności lub zwalnianych z zakładów karnych, osób z zaburzeniami psychicznymi, osób bezdomnych, uchodźców i innych (wskazanych w ustawie). Zamawiający może również określić procentowy wskaźnik zatrudnienia osób należących do jednej wymienionych wyżej 
grup, jednak musi on być nie mniejszy niż 30\% osób zatrudnionych przez wykonawcę (Prawo zamówień publicznych, 2004, art. 22, pkt. 2 i 2a).

\subsection{Kryteria oceny ofert}

Do najchętniej stosowanych w praktyce kryteriów oceny ofert należy cena. Jest to kryterium przejrzyste, obiektywne, łatwe w użyciu. Jednak niska cena nabycia produktu często nie jest najbardziej opłacalna dla zamawiającego. Może się wiązać z krótkim okresem użytkowania, wysokimi kosztami eksploatacji (w tym z wysokim zużyciem energii elektrycznej) lub napraw. Tanie produkty często generują też większe zanieczyszczenie środowiska naturalnego niż ich droższe odpowiedniki.

Nowelizacja ustawy Prawo zamówień publicznych wprowadziła możliwość stosowania innego niż cena kryterium finansowego: kryterium rachunku kosztów cyklu życia produktu. Koszty te obejmują koszty nabycia, użytkowania, utrzymania, wycofania z eksploatacji, a także koszty przypisywane ekologicznym efektom zewnętrznym, dotyczące m.in. emisji gazów cieplarnianych i innych zanieczyszczeń. Warunkiem zastosowania takich kalkulacji jest możliwość określenia i zweryfikowania wartości pieniężnej poszczególnych efektów oraz przedstawienia przez zamawiającego metody obliczania kosztu cyklu życia (Prawo zamówień publicznych, 2004 , art. 91, art. 2, 3b i 3c).

\section{Wdrożenie zasad „zrównoważonych zamówień publicznych" w Polsce}

\subsection{Działania administracji państwowej}

Stosowanie zasad ZZP wymaga od zamawiających wiedzy i dodatkowego wysiłku w stosunku do zamówień, które ich nie uwzględniają. Wynika stąd konieczność podejmowania przez Urząd Zamówień Publicznych działań wspierających i promujących ideę. Podstawą tych działań w latach 2013-2016 był Krajowy Plan Działań w zakresie zrównoważonych zamówień publicznych na lata 2013-2016 (UZP, 2013).

W 2016 roku aktywność Urzędu Zamówień Publicznych związana była głównie z nowelizacją ustawy Prawo zamówień publicznych. W celu umożliwienia pozyskania przez zamawiających wiedzy o zmianach, UZP zorganizował wiele szkoleń centralnych i konferencji regionalnych. Prezentacje ze szkoleń dostępne są na stronie internetowej Urzędu. Również w ramach XXVI Forum Ekonomicznego w Krynicy odbyły się dwa panele dyskusyjne dotyczące aspektów społecznych w zamówieniach publicznych (UZP, 2016c, s. 13-15). 
Istotną rolę edukacyjną spełniają informacje i publikacje zamieszczone na stronie internetowej Urzędu Zamówień Publicznych. Stale rozbudowywane są zakładki „Zielone zamówienia” i „Społeczne zamówienia”. Bezpłatnie dostępne są podręczniki w wersji cyfrowej, np. „Aspekty społeczne w zamówieniach publicznych”, „Ekologiczne zakupy! Podręcznik dotyczący zielonych zamówień publicznych”, "Zielone zamówienia publiczne - zbiór dobrych praktyk" oraz dużo analiz, opinii i tłumaczeń przydatnych dokumentów.

Urząd Zamówień Publicznych stara się rozwiązywać problemy pojawiające się w praktyce. Przykładem takiego problemu jest stosowanie zapisów o zatrudnieniu pracowników na podstawie umowy o pracę i konieczność zapewnienia przestrzegania ciążących na zamawiających i wykonawcach obowiązków z tym związanych. Wyjaśnienia wymagało zastosowanie $\mathrm{w}$ tym przypadku przepisów o przetwarzaniu danych osobowych. W tym celu Urząd Zamówień Publicznych zwrócił się z prośbą o opinie: do Generalnego Inspektora Ochrony Danych Osobowych oraz do Głównego Inspektora Pracy. Uzyskane opinie opublikowano w serwisie internetowym.

Kolejne działania UZP dotyczą opracowania nowego „Planu Działań w zakresie zrównoważonych zamówień publicznych na lata 2017-2020" oraz promocji dobrych praktyk i publikacji wzorcowych zapisów w dokumentacji zamówienia (UZP, 2016c, s. 15).

W 2015 roku Rada Ministrów zobowiązała instytucje administracji rządowej do dokonywania zamówień publicznych w sposób wspierający politykę społeczną. 28 lipca 2015 Rada Ministrów przyjęła „Zalecenia Rady Ministrów w sprawie stosowania przez administrację rządową klauzul społecznych w zamówieniach publicznych" (UZP, 2015). Na mocy wyżej wymienionego dokumentu instytucje administracji rządowej zobowiązane są do analizowania możliwości zastosowania klauzul społecznych we wszystkich postępowaniach.

\subsection{Zakres stosowania zasad „Zrównoważonych zamówień publicznych” w latach 2013-2015}

Urząd Zamówień Publicznych monitoruje proces stosowania zasad ZZP w postępowaniach przetargowych przeprowadzonych przez polskie instytucje. Losową próbę ogłoszeń poddaje się analizie pod względem: przedmiotu zamówienia, warunków udziału w postępowaniu, kryteriów oceny ofert, wymagań związanych z realizacją zamówienia oraz dokonanych zastrzeżeń zamówienia. Na tej podstawie wyznaczany jest wskaźnik „zazielenienia” oraz „uspołecznienia” zamówień publicznych (UZP, 2016a, s. 76-77). Wyniki powyższych analiz dla lat 2013-2015 przedstawiono w tabeli 1.

Przedstawione dane wskazują na niewielkie rozpowszechnienie stosowania ZZP. W latach 2013-2015 nie można również zauważyć tendencji wzrostowej w tej dziedzinie. Być może zmiany prawne oraz różnego rodzaju działania ze strony 
organów państwa na rzecz uwzględniania zagadnień społecznych i ekologicznych w zamówieniach publicznych przyniosą zapowiadany na 2016 rok skokowy wzrost.

Tabela 1. Poziom zazielenienia i uspołecznienia zamówień publicznych polskich instytucji w latach 2013-2015

\begin{tabular}{|c|c|c|c|c|}
\hline ROK & 2013 & 2014 & 2015 & $\begin{array}{c}2016 \\
\text { - zakładany poziom }\end{array}$ \\
\hline Poziom zazielenienia & $12,1 \%$ & $9,25 \%$ & $11,4 \%$ & $20 \%$ \\
\hline Poziom uspołecznienia & $4,5 \%$ & $3,1 \%$ & $4,08 \%$ & $10 \%$ \\
\hline
\end{tabular}

Źródło: opracowanie własne na podstawie UZP, 2016a, s. 77

\subsection{Bariery stosowania zasad „Zrównoważonych zamówień publicznych” w praktyce}

Identyfikacja barier stosowania zasad ZZP opiera się na następujących informacjach i badaniach:

- wyniki badania ankietowego przeprowadzonego przez Urząd Zamówień Publicznych wśród 59 respondentów, głównie przedstawicieli jednostek samorządu terytorialnego (UZP, 2012),

- wyniki badania przeprowadzonego metodą wywiadu częściowo ustrukturyzowanego na próbie 16 respondentów reprezentujących wszystkie strony związane z zamówieniami publicznymi (przedstawiciele instytucji zamawiających różnych szczebli, wykonawcy, partnerzy społeczni, przedstawiciele ciał odwoławczych, trenerzy prowadzący szkolenia w tej dziedzinie i inne osoby zaangażowane $\mathrm{w}$ proces zamówień publicznych) (Faracik i Szymonek, 2015),

- analiza powodów unieważnień przetargów w 2015 r. wskazanych w publikacji Urzędu Zamówień Publicznych (UZP, 2016d),

- przegląd wyników wyżej wymienionych badań pozwala na wyróżnienie trzech grup barier stosowania zasad ZZP w praktyce.

Pierwszą grupę stanowią bariery związane $\mathrm{z}$ wiedzą $\mathrm{i}$ umiejętnościami po stronie zamawiających i osób sprawujących funkcje kontrolne. Zarówno w badaniu ankietowym, jak i w wywiadach respondenci wskazywali na: zbyt niski poziom edukacji i świadomości na temat ZZP, niewystarczającą ilość i różnorodność materiałów praktycznych, dobrych praktyk i modelowych rozwiązań oraz brak stosownej wiedzy wśród organów kontrolnych. Według ankietowanych, kontrolujący mogą uznać przetarg uwzględniający zasady ZZP za przeprowadzony nieprawidłowo (UZP, 2012, s. 2), (Faracik, Szymonek, 2015 s. 39). Można również zauważyć, że skuteczne wdrożenie zasad ZZP wymaga od instytucji zamawiających prowadzenia określonej 
polityki społecznej, gospodarczej i środowiskowej. To z kolei wiąże się z koniecznością analizy i monitoringu wyżej wymienionych zagadnień.

Druga grupa to bariery psychologiczne, związane z postawami lub obawami osób zamawiających. W tej grupie dominuje kwestia obaw co do oceny poprawności przeprowadzenia przetargu oraz ryzyka zarzutów o ograniczenie zasad wolnej konkurencji, niegospodarność lub naruszenie zasad dyscypliny finansów publicznych. Respondenci, z którymi przeprowadzono wywiad, mówili również, że problemem jest „brak woli, mentalność, tendencja do schematycznego myślenia i chodzenie utartymi ścieżkami oraz wygoda urzędników i decydentów, którzy nie chcą niczego zmieniać, zarówno z braku chęci nabycia wiedzy dotyczącej ZZP, jak i z braku przekonania co do potrzeby jej wdrożenia” oraz „brak świadomości korzyści wynikających z zastosowania ZZP, szczególnie na poziomie gmin i powiatów, a jednocześnie zrozumienia, że skuteczne zastosowanie klauzul wymaga identyfikacji problemów/ polityk, które mają być wspierane przez ZZP” (Faracik, Szymonek, 2015, s. 39).

Odrębny problem stanowi bariera finansowa. $\mathrm{O}$ tym, że jest to bariera istotna, można wnioskować na podstawie informacji o przetargach z zastosowaniem klauzul społecznych w 2015 roku. Przetargi tego rodzaju są często unieważniane (73 na 437 przypadków), najczęstszym powodem unieważnień była zbyt wysoka cena - przekraczała kwotę, którą zamawiający zamierzał przeznaczyć na sfinansowanie zamówienia (UZP, 2016d, s. 20). W wielu przypadkach spełnienie zasad ZZP obiektywnie podnosi koszt realizacji zamówienia, co niewątpliwie stanowi dylemat dla podmiotów odpowiedzialnych za gospodarowanie środkami publicznymi.

\section{Propozycje działań zmierzających do upowszechnienia realizacji zasad „Zrównoważonych zamówień publicznych”}

Identyfikacja barier stosowania zasad ZZP w praktyce pozwala na zaproponowanie działań zmierzających do ich przezwyciężenia.

Bariery związane $\mathrm{z}$ wiedzą i umiejętnościami zamawiających likwidowane są poprzez działania edukacyjne. Takie działania są prowadzone przez Urząd Zamówień Publicznych (opisane w podrozdziale 4.1 niniejszego artykułu).

Bariery finansowe w stosowaniu zasad ZZP mogą być zmniejszane w dwojaki sposób:

- zapewnienie dodatkowych środków dla instytucji publicznych stosujących zasady ZZP (stworzenie funduszu, $\mathrm{z}$ którego instytucje publiczne mogłyby otrzymywać dodatkowe środki na zakupy spełniające postulaty zamówień zrównoważonych),

- wymuszenie tworzenia $\mathrm{w}$ instytucjach publicznych rezerwy na pokrycie dodatkowych kosztów wynikających z realizacji zasad ZZP, poprzez odpowiednie regulacje prawne. 
Przezwyciężanie barier psychologicznych stanowi - w ocenie autorki niniejszej pracy - największe wyzwanie. Wymaga podjęcia działań kompleksowych i długoterminowych. Obawy osób zamawiających o to, że zostaną posądzone o niegospodarność bądź nieprawidłowe przeprowadzenie przetargu mogą się zmniejszać wraz $z$ realizacją działań edukacyjnych oraz znoszących bariery finansowe. Jednak niechęć do wprowadzania nowych rozwiązań z powodu konieczności podjęcia dodatkowego wysiłku, negatywny stosunek do zmian oraz brak przekonania co do potrzeby wspierania zrównoważonego rozwoju - to bariery, których przezwyciężenie jest niezwykle trudne. Do działań, które można zaproponować w tym obszarze, należą zmiany w kulturze organizacyjnej wielu instytucji publicznych, zmiany kadrowe oraz promocja idei zrównoważonego rozwoju $\mathrm{w}$ całym społeczeństwie. $\mathrm{Z}$ uwagi na to, że stosowanie zasad ZZP wymaga od pracowników dodatkowego wysiłku, konieczne jest również wdrożenie narzędzi motywowania osób odpowiedzialnych za realizację zamówień: bodźców płacowych (premie, nagrody) oraz pozapłacowych (np. pochwały, kontrola pracy, ocena pracownicza, możliwość awansu).

\section{Podsumowanie}

Teoria „zrównoważonych zamówień publicznych” wydaje się bardzo prosta i zrozumiała. Jednak upowszechnienie stosowania tej teorii w praktyce napotyka na wiele barier. Wymaga od zamawiających określonych postaw, wiedzy, umiejętności i dodatkowego wysiłku. Dlatego dla realizacji zasad ZZP konieczne jest podjęcie działań ze strony administracji centralnej, w szczególności ze strony Urzędu Zamówień Publicznych.

Do najbardziej pożądanych działań wspierających upowszechnienie idei ZZP zaliczyć należy:

- działania edukacyjne w zakresie możliwości stosowania zasad ZZP oraz celowości ich stosowania,

- działania zmierzające do wyrównania kosztów zamówień spełniających i niespełniających zasady ZZP z punktu widzenia instytucji zamawiającej,

- wprowadzenie narzędzi motywowania pracowników odpowiedzialnych za zamówienia publiczne w poszczególnych instytucjach do podjęcia dodatkowego wysiłku związanego z realizacją idei zamówień zrównoważonych.

\section{BIBLIOGRAFIA}

[1] Faracik B., Szymonek J., 2015, Zrównoważone zamówienia publiczne. Możliwości, bariery, strategie, Fundacja Kupuj Odpowiedzialnie, Warszawa.

[2] Fundacja Centrum CSR.PL, 2014, Zrównoważone Zamówienia Publiczne w praktyce. Modelowe klauzule społeczne i środowiskowe, Warszawa. 
[3] Strategia Bezpieczeństwo Energetyczne i Środowisko - perspektywa do 2020 r., 2014, Monitor Polski, poz. 469.

[4] Strategia - Sprawne Państwo 2020 - Dynamiczna Polska, 2013, Monitor Polski, poz. 136.

[5] Strategia Rozwoju Kapitału Społecznego, 2013, Monitor Polski, poz. 378.

[6] Ustawa z 29 stycznia 2004 r. Prawo zamówień publicznych, Dz.U. 2015, poz. 2164 ze zmianami.

\section{NETOGRAFIA}

[1] Kancelaria Prezesa Rady Ministrów, 2014, Nowe prawo zamówień publicznych: koniec dyktatu najniższej ceny, https://www.premier.gov.pl/wydarzenia/aktualnosci/nowe-prawo-zamowienpublicznych-koniec-dyktatu-najnizszej-ceny.html (15.10.2016).

[2] Komisja Europejska, 2010, Strategia na rzecz inteligentnego i zrównoważonego rozwoju sprzyjającego włączeniu społecznemu, http://ec.europa.eu/eu2020/pdf/1_PL_ACT_part1_v1.pdf (23.11.2016).

[3] Komisja Wspólnot Europejskich, 2008, Komunikat Komisji do Parlamentu Europejskiego, Rady Europejskiej, Europejskiego Komitetu Ekonomiczno - Społecznego oraz Komitetu Regionów, Zamówienia publiczne na rzecz poprawy stanu środowiska, https://www.uzp.gov.pl/_data/ assets/pdf_file/0022/26518/ KOM-2008-400_Zamowienia-publiczne-na-rzecz-poprawy-stanusrodowiska.pdf (23.11.2016).

[4] Sustainable Procurement Platform, 2016, What is Sustainable Procurement?, http://www. sustainable -procurement.org/about-spp/ (25.10.2016).

[5] UZP, 2012, Wyniki badania ankietowego dotyczącego stosowania klauzul społecznych przez polskie instytucje zamawiajace, starastrona.uzp.gov.pl/cmsws/page/GetFile1.aspx?attid=6426 (23.11.2016).

[6] UZP, 2013, Krajowy Plan Działań w zakresie zrównoważonych zamówień publicznych na lata 2013-2016. https://www.uzp.gov.pl/_data/assets/pdf_file/0019/26353/KPD_ZZP_2013_2016. $\operatorname{pdf}(15.11 .2016)$.

[7] UZP, 2015, Zalecenia Rady Ministrów w sprawie stosowania przez administrację rządową klauzul społecznych $w$ zamówieniach publicznych, https://www.uzp.gov.pl/_data/assets/pdf_file/0024/26637/ zalecenia_Rady_Ministrow_klauzule_spoleczne.pdf (26.11.2016).

[8] UZP, 2016a, Sprawozdanie Prezesa Urzędu Zamówień Publicznych o funkcjonowaniu systemu zamówień publicznych w 2015 r., https://www.uzp.gov.pl/_data/assets/pdf_file/0025/32389/ Sprawozdanie-Urzedu-Zamowien-Publicznych-za-rok-2015.pdf (23.10.2016)

[9] UZP, 2016b, Społeczne zamówienia. Podstawowe informacje, https://www.uzp.gov.pl/baza-wiedzy/zrownowazone-zamowienia-publiczne/spoleczne-zamowienia/podstawowe-informacje (14.10.2016).

[10] UZP, 2016c, Informator Urzędu Zamówień Publicznych nr 3/2016, https://www.uzp.gov.pl/_data/ assets/ pdf_file/0019/32815/Informator_nr_3_2016.pdf (25.11.2016).

[11] UZP, 2016d, Wyniki monitoringu stosowania przez administracje rządowa klauzul społecznych w zamówieniach publicznych za 2015 r., https://www.uzp.gov.pl/_data/assets/pdf_file/0019/32428/ Wyniki_moni toringu_stosowania_klauzul_spolecznych....pdf (30.11.2016). 